\title{
Molecular and Morphological Diversity Studies of Five Cola (Schott and Endl.) Species in Ibadan, Nigeria
}

\author{
ThankGod Timipanipiri Wood ${ }^{1}$ and Elijah Ige Ohimain ${ }^{2^{\star}}$ \\ ${ }^{1}$ Plant Genetics and Molecular Biology, Botany Department, University of Ibadan, Nigeria. \\ ${ }^{2}$ Department of Microbiology, Niger Delta University, Wilberforce Island, Bayelsa State, Nigeria.
}

\begin{abstract}
Authors' contributions
This work was carried out in collaboration between both authors. Author TGTW designed the study, performed the statistical analysis, wrote the protocol and wrote the first draft of the manuscript. Author EIO managed the analyses of the study and upgraded the manuscript. Both authors read and approved the final manuscript.

Article Information

DOI: 10.9734/ARRB/2020/v35i930266

Editor(s):

(1) Dr. Bechan Sharma, University of Allahabad, India

Reviewers:

(1) Tumuhe Charles Lwanga, Makerere University, Uganda. (2) Vinod Kumari, Panipat Institute of Engineering and Technology (PIET), India. (3) Susmita Sahoo, Natubhai V. Patel College of Pure and Applied Sciences (NVPAS), India. Complete Peer review History: http://www.sdiarticle4.com/review-history/60214
\end{abstract}

Original Research Article

Received 06 June 2020

Accepted 12 August 2020

Published 22 August 2020

\section{ABSTRACT}

Intra- and inter-species genetic diversity study was carried out comparing the molecular and morphological characters of five Cola species namely Cola acuminata, Cola nitida, Cola millenii, Cola lepidota and Cola gigantea collected from five locations in Ibadan, Nigeria. Sixteen Cola accessions were analysed based on 7 quantitative characters, 12 qualitative characters and 8 Random Amplified Polymorphic DNA primers. From the quantitative characters studied, high significant difference across the location and species was recorded as leaf length had the strongest variability while the species obtained from Botany Nursery showed strongest locational effect on the vegetative leaf characters. All quantitative characters analysed were good determinants for delimiting Cola species. Cola lepidota recorded the highest variability compared to the other Cola species. Qualitative characters studied revealed that leaf surface, seed colour, and floral colour are strong characters for delimiting Cola species. Molecular analysis showed that 309 fragments were recorded, of which $28.5 \%$ were polymorphic while $8.4 \%$ were monomorphic. Genetic similarities 
ranged from 0.44 to 0.93 for the 16 Cola accessions with a mean value of 0.67 . Deductions from the combined effect of molecular and morphological characters showed high variability for the characters analysed and a likely monophyletic relationship for the 16 Cola accessions. Molecular and morphological determinants observed in this study can help Cola breeders identify species of interest. We recommend further research on the variability of Cola species.

Keywords: Accessions; genetic diversity; kola nut; medicinal plant.

\section{INTRODUCTION}

The kola nut is the fruit of the medicinal tree called Cola species, which is indigenous to West Africa. The kola plant belongs to the Cola genus of Sterculiaceae family that has over one hundred and twenty-five known species [1]. Cola acuminata (Beauvoir) Schott and Endlicher known as (Obi abata in Yoruba) and Cola nitida (Vent.) Schott and Endl. known as (Obi gbanja in Yoruba) are rich in caffeine (2-3\%). Theobromin and kolanin are the most important metabolites in Cola species based on their social, pharmacological and economic importance. Cola gigantea (A. Chev.) traditionally called " oporoporo" is an African medicinal plant, whose powdered back is used for the cure of venereal diseases, headache, intestinal and lumber pain [2]. On the other hand, Cola lepidota K. Schum. is a tree of about $18 \mathrm{~m}$ high that has soft and fibrous bark. Cola millenii and Cola gigantea are widely distributed in wet and dry forest environments [3].

Generally, the common morphological traits of the leaves of Cola species are simple, entire and narrowed or rounded towards the base. The arrangement of the leaves on the stem is alternate in some species and verticillate in others, in whorls of 3 or 4 . However, the variability within the Cola genus cuts across morphological, phytochemical and anatomical grounds. Molecular systematics is still regarded as the most accurate form of clearing doubts relating to diversity among species. DNA markers are currently used as molecular tool to show any diversity within the evolutionary line and the significant closeness between them. Morphologically, both quantitative and qualitative characters can also be used to characterize and classify within and between species.

Morphological characters have been widely used in the evaluation of various crops. Exploitation of the qualitative and quantitative traits can be a good taxonomic tool for knowing the genetic variability present within a population of related species. Results obtained from morphological characterization strongly facilitate genetic diversity studies and future breeding programs based on geographical adaptability [4]. Several morphological descriptors from the leaves, fruits, branches, plant heights and other reproductive parts of the plants are essential tools for characterization [5]

Random Amplified Polymorphic DNA (RAPD) markers are "Decamer" (10 nucleotide length) DNA fragments from polymerase chain reaction (PCR) amplification of random segments of genomic DNA with single primer of arbitrary nucleotide sequence and which are able to differentiate between genetically distinct individuals, although not necessarily in a reproducible manner [5]. It is used to analyse the genetic diversity of an individual by using random primers. RAPD requires only one primer for amplification. Unlike traditional Polymerase Chain Reaction (PCR) analysis, RAPD does not require any specific knowledge of the DNA sequence of the target organism [5].

Due to the importance of kola nut in beverages and medicinal use, it became necessary to characterize the plant and possibly establish the relationship between different species. The objective of the study is to carry out a comparative study on five Cola species, seven morpho-quantitative characters and twelve qualitative characters of sixteen Cola accessions collected from five locations in Ibadan and analysed for their intra- and inter-species relationship. Also, the DNAs of the 16 Cola accessions collected at five locations were analysed using RAPD forward primers. This molecular analysis is expected to reveal the gene diversity, genetic distance, and allele polymorphism among the five different Cola species.

\section{MATERIALS AND METHODS}

\subsection{Germplasm Location}

Cola species were collected from five locations in Ibadan, Nigeria namely; Cocoa Research 
Institute of Nigeria (CRIN), National Centre for Genetic Resource and Biotechnology (NACGRAB), Dabiri village in Akinyele, Local Government Area (LGA) Botanical Garden of University of Ibadan (UI) and Botany Department nursery of University of Ibadan. Each location has a unique eco-diversity characterized by dense rainforest environment, tall trees, rich humus to poorly loamy soil, and tropical agro ecological environment.

\subsection{Sample Collection}

A total of 16 samples from the Five locations, and 10 replicates were collected at random representing five species of Cola species with an uneven spread per location. Various Cola species were collected at different locations in Ibadan. Mature leaves of Cola acuminata, Cola nitida, Cola gigantea, Cola lepidota and Cola milleni from tree stands that are over 10 years of age were collected and properly identified by the Herbarium Unit, Botany Department, University of Ibadan.

\subsection{Morphological Data Analysis}

A total of 19 macro-morphological characters of both qualitative and quantitative descriptors were collected across the five locations based on their unique eco diversity and climatic conditions. With the aid of transparent rule, masking tape, a rope and visual aid, quantitative measurements were taken of leaf apex, leaf margin, leaf petiole length, leaf base, collar length, petiole diameter, leaf shape, leaf length, plant height and leaf width. The quantitative characters were obtained by measurement of the leaves in centimetres and counting characters observed. Qualitative characters of the samples collected were scored based on visual evaluation by scoring the variations in leaf apex, leaf shape, leaf margin, leaf base and leaf surface, flower shape, and seed colour.

Multivariate numerical techniques including analysis of variance, correlation and cluster analyses for the 19-character traits were employed to evaluate the taxonomic relationship from the morphological and molecular data obtained. The data obtained were subjected to the statistical analysis using Statistical Analysis Software (SAS) version 9.0 (SAS Inc., Cary, NC, USA). Every character under this statistical analysis were given equal weight. Between two Cola species, the overall similarities were a function of their individual similarities in each of the 12 descriptors they were compared with.
The degree of resemblance among species were measured by the correlation coefficient of the characters across the 16 samples or "Operational Taxonomic Units (OTUs). Cluster analysis of the OTUs based on the percentage similarity was carried out to enable the construction of a precise dendrogram showing the degree of resemblance at various levels and the clustering of OTUs according to their similarities. Comparative morphological studies were carried out through the characterization of the qualitative and quantitative characters of the16 Cola stands across five germplasm location in Ibadan, Nigeria.

\subsection{Molecular Analysis}

Young healthy fresh leaves obtained from young branches of each tree stand were collected from the five species across the five locations. A total 16 leaf samples were collected into a temporary preservation box, which were immediately hermetically sealed and packed in ice for transportation to the laboratory. The samples were subsequently stored in the freezer at $-20^{\circ} \mathrm{C}$ until required for analysis. The molecular analysis was carried out in the Bioscience Lab, International Institute for Tropical Agriculture (IITA) Ibadan, Nigeria. DNA extraction from Cola samples was done using DNA Kit extraction protocol. The yield and purity of the DNA extracted is presented in Table 1.

\subsection{RAPD Analysis}

All RAPD primers (Table 2) were standardized to a $25 \mu \mathrm{g} / \mathrm{ml}$ stock solution. DNA amplification was performed. The DNA was subjected to the following cocktail mix and conditions for the PCR. 10× PCR buffer $(1 \mu \mathrm{l}), 50 \mathrm{mM} \mathrm{Mgcl} 2(0.4 \mu \mathrm{l}), 5$ pMol forward primer $(0.5 \mu \mathrm{l}), 5$ pMol reverse primer. Each reaction tube was then overlaid with mineral oil, in order to seal the tube and prevent evaporation, and amplified on a DNA master cycler (Bio Oven III). The reaction mixture was subjected to a 40 amplification cycles.

\subsection{Sample Preparation for Electrophoresis}

The amplification products were subjected to electrophoresis by mixing $4 \mu \mathrm{l}$ of the DNA fragments and $2 \mu \mathrm{l}$ of loading dye together and loading them in the well of a $1.5 \%$ Agarose gel. The sample electrophoresed for 1 hour 30 minutes at a constant voltage of 80 volt, $300 \mathrm{~mA}$ 60 Watt. The plates were dismantled and the 
gels were stained by placing it in Ethiduim bromide $(5 \mathrm{mg} / \mathrm{ml})$ for 5 minutes. The gels were also viewed under the illuminator, photographed and the pictures saved.

\subsection{Scoring of Bands}

The presence of DNA bands were scored as Present (1) or Absent (0), and each band was regarded as a locus. The result obtained was used to create the binary data set and entered into a binary data matrix as discrete variables to generate a data matrix. The binary data obtained from scoring the RAPD bands were used to evaluate the relationship of the five Cola species across five locations. A similarity matrix was generated from the binary data using Jaccard's similarity coefficient

Table 1. Yield and purity index of extracted Cola genomic DNA

\begin{tabular}{|c|c|c|c|c|}
\hline Sample ID & & ABBREV. & $\begin{array}{l}\text { DNA yield ( } \mu \mathrm{g} / \text { of fresh } \\
\text { weight) }\end{array}$ & A260/280* \\
\hline 1 & Cola acuminata (CRIN) & CCA & 78.00 & 0.96 \\
\hline 2 & Cola nitida (DABIRI) & $\mathrm{ACN}$ & 205.30 & 1.35 \\
\hline \multirow[t]{2}{*}{3} & Cola acuminata (BOT & & & \\
\hline & GARDEN) & GCA & 345.70 & 1.62 \\
\hline 4 & Cola acuminata (DABIRI) & ACA & 699.80 & 1.56 \\
\hline 5 & Cola nitida (BOT GARDEN) & GCN & 421.20 & 1.65 \\
\hline 6 & Cola melenii (DABIRI) & ACM & 989.00 & 1.65 \\
\hline 7 & Cola melenii (NACGRAB) & NACM & 1139.80 & 1.72 \\
\hline \multirow[t]{2}{*}{8} & Cola melenii (BOT. & & & \\
\hline & NURSERY) & NCM & 1651.10 & 1.78 \\
\hline 9 & Cola melenii (BOT. GARDEN) & GCM & 810.60 & 1.70 \\
\hline 10 & Cola gigantea (NACGRAB) & NACG & 1265.30 & 1.23 \\
\hline \multirow[t]{2}{*}{11} & Cola gigantea (BOT. & & & \\
\hline & GARDEN) & GCG & 444.30 & 1.21 \\
\hline 12 & Cola gigantea (DABIRI) & ACG & 272.60 & 1.20 \\
\hline 13 & Cola nitida (CRIN) & $\mathrm{CCN}$ & 616.10 & 1.38 \\
\hline 14 & Cola acuminata (NACGRAB) & NACN & 1374.50 & 1.40 \\
\hline 15 & Cola nitida (BOT. NURSERY) & $\mathrm{NCN}$ & 330.20 & 1.57 \\
\hline \multirow[t]{2}{*}{16} & Cola lepidota (BOT. & & & \\
\hline & NURSERY) & $\mathrm{NCL}$ & 518.60 & 1.63 \\
\hline
\end{tabular}

Table 2. Primers used, number of amplified polymorphic bands, PIC and gene diversity

\begin{tabular}{llllll}
\hline Primer ID & Primer Sequence & $\begin{array}{l}\text { No. of } \\
\text { Polymorphic } \\
\text { DNA bands }\end{array}$ & $\begin{array}{l}\text { Allele } \\
\text { number }\end{array}$ & $\begin{array}{l}\text { Gene } \\
\text { diversity }\end{array}$ & $\begin{array}{l}\text { Polymorphic } \\
\text { information } \\
\text { content }\end{array}$ \\
\hline OPT - 06 & -5 - CAAGGGCAGA - 3 & 10 & 10 & 0.24 & 0.95 \\
OPT - 07 & -5 - GGCAGGCTGT - 3 & 15 & 6 & 0.22 & 0.99 \\
OPT - 20 & 5 - GACCAATGCC - 3 & 10 & 10 & 0.19 & 0.92 \\
OPB - 10 & 5 - CTGCTGGGAC - 3 & 11 & 10 & 0.19 & 0.98 \\
OPH - 02 & - 5 - TCGGACGTGA - 3 & 7 & 8 & 0.13 & 0.81 \\
OPH - 05 & - 5 - AGTCGTCCCC - 3 & 10 & 8 & 0.16 & 0.94 \\
OPT - 01 & - 5 - GGGCCACTCA - 3 & 13 & 8 & 0.20 & 0.97 \\
OPT - 04 & - 5 - CACAGAGGGA -3 & 12 & 7 & 0.19 & 0.97 \\
Mean & & 11 & 8.4 & 0.19 & 0.94 \\
\hline \multicolumn{5}{r}{} \\
\hline
\end{tabular}

\section{RESULTS}

\subsection{Morphological Parameters}

Among all the vegetative characters used for this study, the leaf length stood out as the character with the highest variability both for the location and species (Table 3 ). The high significance obtained in the 
correlation matrix (Table 4) show that the leaf length is the strongest vegetative character for this study that can be used for delimiting Cola species.

Table 3. Performance of Cola species on Quantitative Characters

\begin{tabular}{lllllll}
\hline Species & $\begin{array}{l}\text { Leaf } \\
\text { length }(\mathbf{c m})\end{array}$ & $\begin{array}{l}\text { Leaf } \\
\text { width }(\mathbf{c m})\end{array}$ & $\begin{array}{l}\text { Leaf petiole } \\
\text { length }(\mathbf{c m})\end{array}$ & $\begin{array}{l}\text { Mid vein } \\
(\mathbf{c m})\end{array}$ & $\begin{array}{l}\text { Collar } \\
\text { length }(\mathbf{c m})\end{array}$ & $\begin{array}{l}\text { Leaf petiole } \\
\text { diameter }(\mathbf{c m})\end{array}$ \\
\hline C. lepidota & $8.84^{\mathrm{c}}$ & $5.13^{\mathrm{c}}$ & $4.44^{\mathrm{c}}$ & $1.64^{\mathrm{c}}$ & $0.31^{\mathrm{c}}$ & $0.04^{\mathrm{c}}$ \\
C. gigantean & $32.47^{\mathrm{a}}$ & $18.11^{\mathrm{a}}$ & $18.67^{\mathrm{a}}$ & $9.67^{\mathrm{a}}$ & $1.1^{\mathrm{a}}$ & $0.23^{\mathrm{a}}$ \\
C. acuminata & $12.14^{\mathrm{c}}$ & $5.02^{\mathrm{c}}$ & $3.79^{\mathrm{c}}$ & $5.18^{\mathrm{b}}$ & $0.54^{\mathrm{b}}$ & $0.16^{\mathrm{b}}$ \\
C. millenii & $26.53^{\mathrm{b}}$ & $13.30^{\mathrm{b}}$ & $11.93^{\mathrm{b}}$ & $5.60^{\mathrm{b}}$ & $0.64^{\mathrm{b}}$ & $0.20^{\mathrm{ab}}$ \\
C. nitida & $13.43^{\mathrm{c}}$ & $5.23^{\mathrm{c}}$ & $2.84^{\mathrm{c}}$ & $5.02^{\mathrm{b}}$ & $0.25^{\mathrm{c}}$ & $0.16^{\mathrm{b}}$ \\
\hline
\end{tabular}

Each value is the mean of 10 replicates. Values with the same alphabet are not significantly $(p<0.05)$ different from one another across the column according to Duncan's Multiple Range

Table 4. Correlation matrix showing the relationship among quantitative characters, location and species effects

\begin{tabular}{|c|c|c|c|c|c|c|c|c|c|}
\hline & LL & LW & LPL & LMV & $\mathrm{CL}$ & LPD & LN & Location & Species \\
\hline LW & $0.92^{* *}$ & & & & & & & & \\
\hline LPL & $0.92^{* *}$ & $0.90^{* *}$ & & & & & & & \\
\hline NLMV & $0.86^{\star *}$ & $0.82^{* *}$ & $0.82^{\star \star}$ & & & & & & \\
\hline $\mathrm{CL}$ & $0.86^{\star *}$ & $0.86^{* \star}$ & $0.85^{\star *}$ & $0.81^{* *}$ & & & & & \\
\hline LPD & $0.84^{* *}$ & $0.77^{\star *}$ & $0.78^{\star *}$ & $0.87^{* *}$ & $0.80^{* *}$ & & & & \\
\hline LN & $0.77^{* *}$ & $0.78^{\star *}$ & $0.84^{* *}$ & $0.79^{\star *}$ & $0.71^{* *}$ & $0.72^{\star *}$ & & & \\
\hline LOCATION & $-0.45^{*}$ & $-0.42^{*}$ & $-0.40^{*}$ & $-0.43^{*}$ & -0.37 & -0.39 & -0.3 & & \\
\hline SPECIES & $0.05 \mathrm{~ns}$ & $-0.05 n s$ & $-0.12 n s$ & $0.08 \mathrm{~ns}$ & $-0.12 n s$ & $0.20 \mathrm{~ns}$ & $-0.10 \mathrm{~ns}$ & $-0.10 \mathrm{~ns}$ & \\
\hline SAMPLES & $-0.08 n s$ & $-0.04 n s$ & $-0.05 n s$ & $-0.01 \mathrm{~ns}$ & $0.03 \mathrm{~ns}$ & $0.04 \mathrm{~ns}$ & $0.01 \mathrm{~ns}$ & $0.01 \mathrm{~ns}$ & 0 \\
\hline
\end{tabular}

From the cluster analysis the dendrogram for quantitative characters showed an interesting pattern that is consistent with earlier taxonomic claims. Similar Cola species irrespective of the location shows likely intra-species relationship. The dendrogram (Fig. 1A) shows three clusters in which one of them is an outlier (non uniformity). Group 1 is made up of 8 uniform OTUs with three subgroups in a seemingly monophyletic relationship. Cola acuminata from three locations namely Botanical Garden, NACGRAB and CRIN as well as Cola nitida CRIN make up Subgroup 1. This shows an intraspecific relationship in Cola acuminata for the 12 qualitative characters used for the study (Table 5 , Fig. 2). Within this subgroup is an inter species relationship with Cola nitida CRIN (Plate 1). Two uniform OTUs of Cola nitida from University of Ibadan (UI) Botany Department Nursery and Akinyele LGA in an Intra-species relationship, makes up the Subgroup 2. In cluster 2, Cola gigantea Akinyele LGA and Cola lepidota UI Botany Department Nursery are non-uniform (outlier) while Cola millenii from all the locations shows an Intra specific relationship for seven morpho-quantitative traits. Cola gigantea
NACGRAB shows an inter species relationship with Cola millenii. Cluster 3 is an Out-group from the other Groups. This shows that Cola gigantea UI Botany Department nursery may be in a separate relationship with the other Taxa.

From the cluster analysis for qualitative character (Fig. 1B), 3 Groups were observed with Group 3 showing a great group made up of thirteen individual Cola OTUs all representing the five Cola species. This shows the possibility that these Cola species originated from the same genus. In Group 2, we see an Intra species relationship of Cola gigantea from two locations namely Akinyele LGA and NACGRAB, in Group 1, Cola millenii NACGRAB acting as non-uniform outlier.

\subsection{Molecular Parameters}

The molecular analysis shows that the purity of DNA of optical density of $260 / 280$ ratio ranges from 0.96 to 1.78 for the 16 Cola OTUs/samples (Table 1). The selected primers generated distinctive products in the range of 78-1651bp. The maximum and minimum number of bands 
produced by the primers are OPT-07 (52), and OPH-02 (18) respectively (Plates 2 and 3 ). A total number of 309 amplified fragments was scored across sixteen operational taxonomic units of Cola genus for the selected primers
(Table 2), and was used to estimate genetic relationships among themselves. Out of 309 fragments obtained, 88 fragments $(28.5 \%)$ were polymorphic while 26 fragments $(8.4 \%)$ were monomorphic.

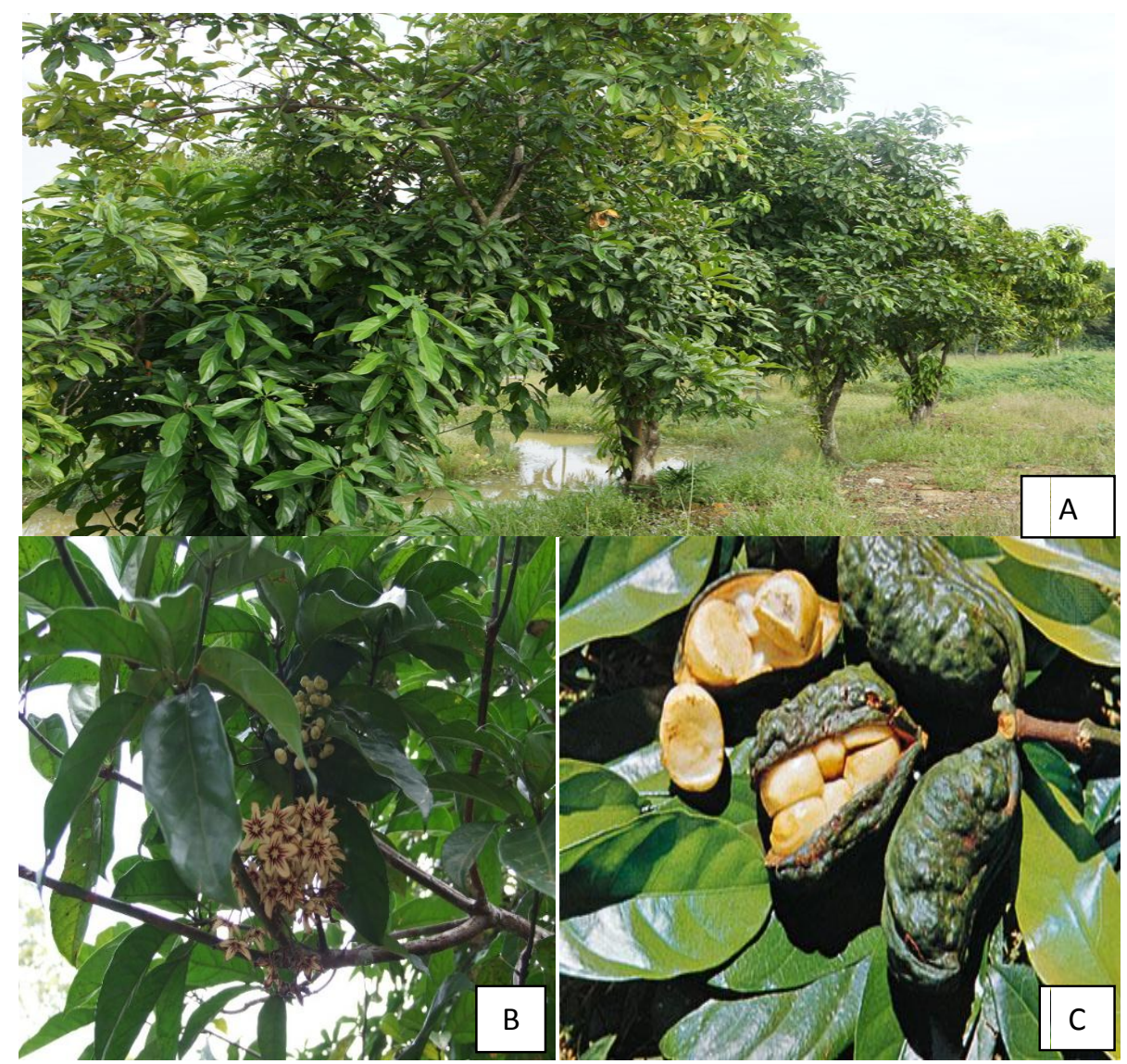

Plate 1. (A, B, C). Cola nitida (Vent.) Schott and Endl. (Obi gbanja) collected at Cocoa Research Institute of Nigeria, CRIN, Ibadan

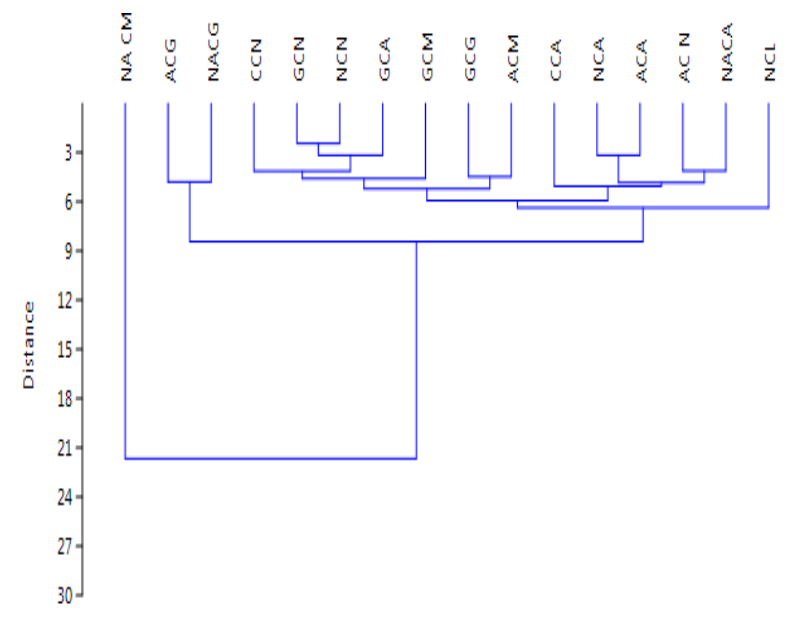

(A) Cluster relationship based on quantitative data 


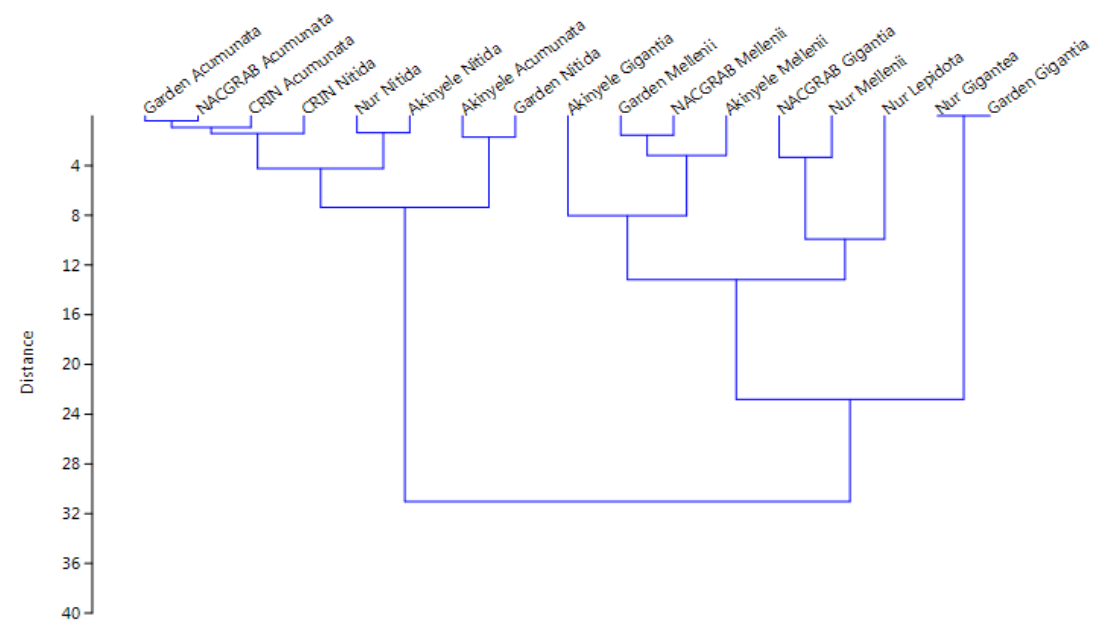

(B) Cluster relationship based on qualitative data

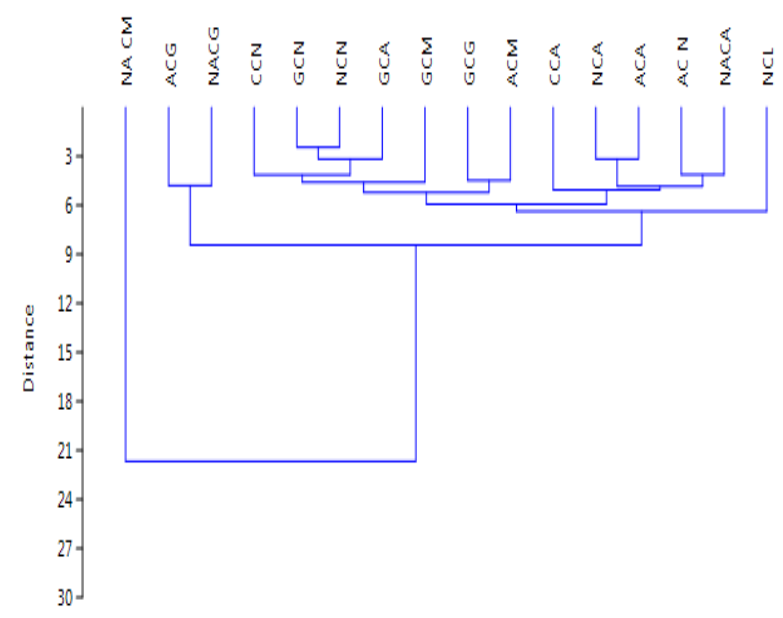

(C) Cluster relationship based on molecular data

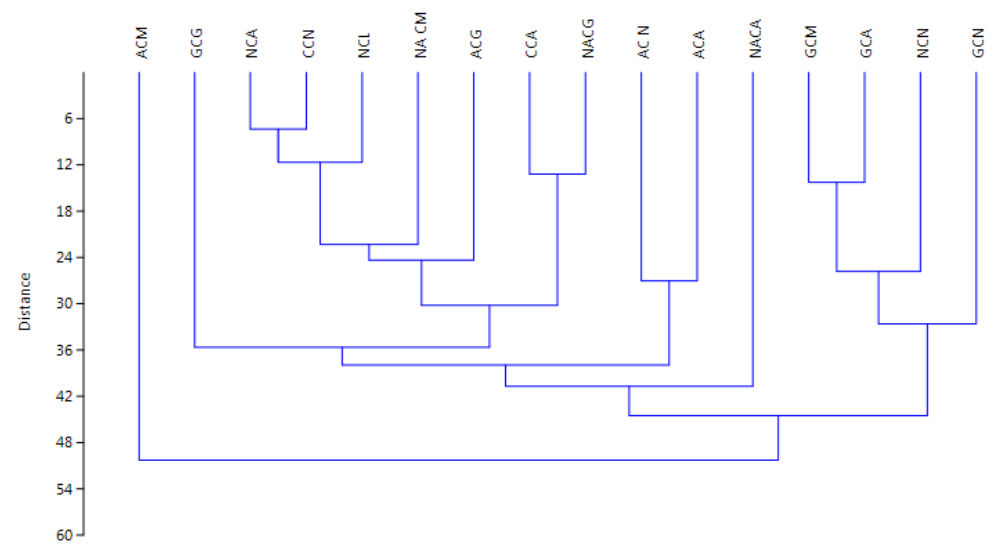

(D) Cluster relationship based on quantitative data + qualitative + molecular

Fig. 1 (A,B,C,D). Dendrograms showing relationship among the 16 Cola accessions/OTUs 


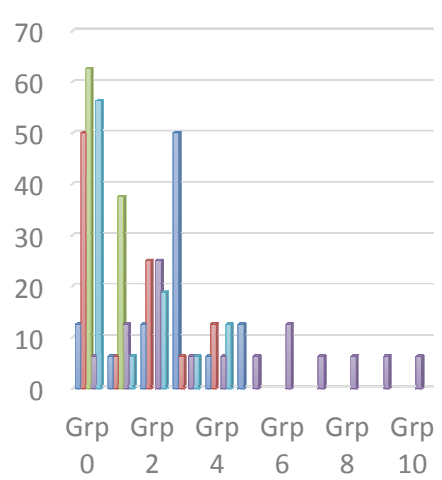

$\square$ base $\square$ apex $\square$ margin $\square$ shape $\square$ surface

Fig. 2. Quantitative frequency of 12 Qualitative characters

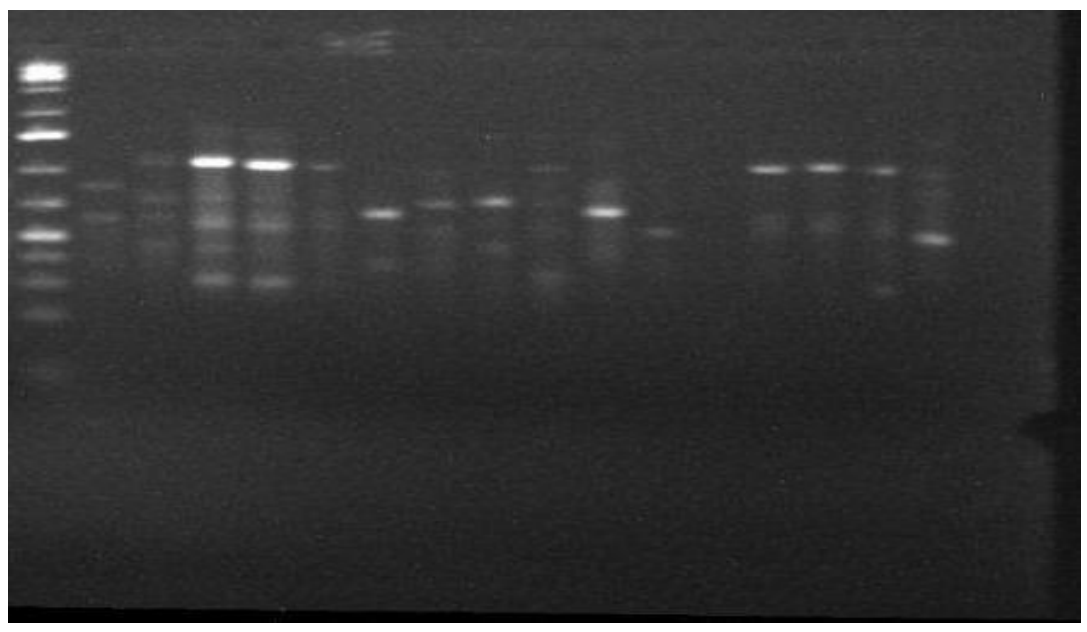

Plate 2. RAPD bands at locus OPT - 20: $1 \mathrm{~KB}+$ Marker, 16 cola samples

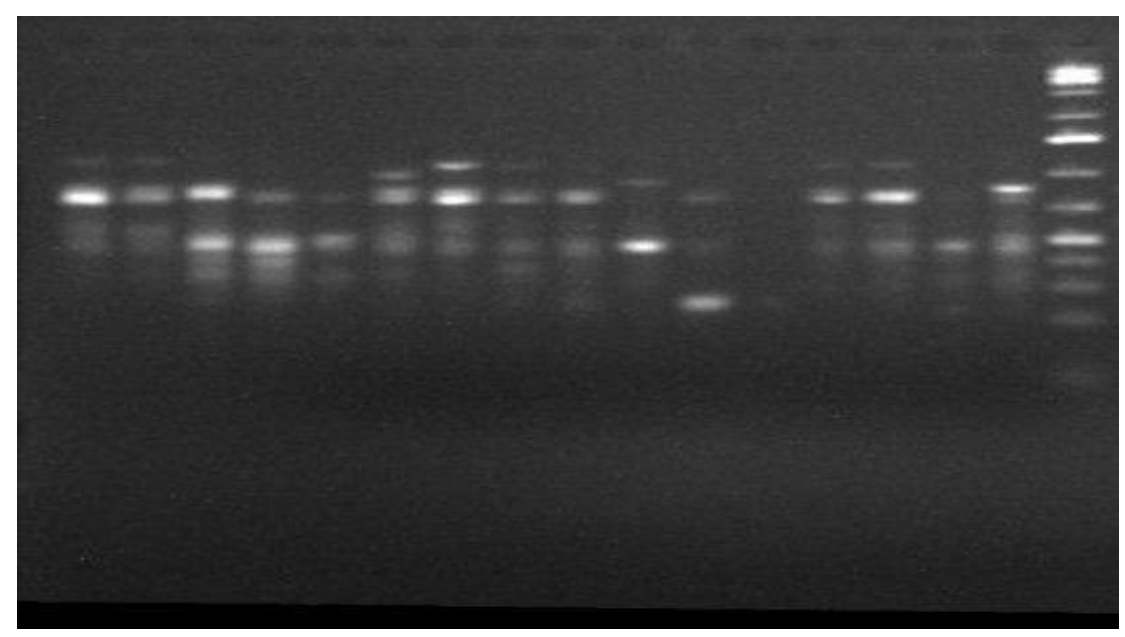

Plate 3. RAPD bands at locus OPT - 07: 1KB+ Marker, 16 cola samples 
Deductions from the amplified products of 16 OTUs in pair-wise genetic similarities ranged from 0.44 to 0.93 in all OTUs with a mean value of 0.67 . The matrix values indicated that these taxa were distantly related to each other. Based on the dendrogram, a great group was observed. Subgroup 1A contain Cola acuminata (CRIN), Cola millenii (NAGRAB) and Cola millenii with similarity of $74 \%$ indicating Intra species relationship. In Sub group 1B, Cola millenii (Botanical Garden), Cola gigantea (Botanical Garden), Cola gigantea (Akinyele LGA), Cola nitida (CRIN) and Cola nitida (NAGRAB) had a similarity coefficient of $79.1 \%$ indicating Intra species relationship. In subgroup 1C, similarity is shown by Cola nitida (Botanical Garden), Cola millenii (Akinyele LGA), Cola nitida (NACGRAB) that is $73 \%$ indicating Intra species relationship. Meanwhile, the similarity between Group 1 and Group 2 is $69 \%$. In lower Group 2, Cola nitida (Akinyele LGA) is out group with similarity coefficient of $63.8 \%$. Group 3 is made up of Cola acuminata (Botanical Garden), Cola acuminata (Akinyele LGA), and Cola nitida (UI Botany Department nursery) with similarity of $70.4 \%$ while the last Group 4 is Cola lepidota with genetic similarity of $55 \%$.

\section{DISCUSSION}

From the results obtained for the quantitative analysis, a strong Inter species and Intra species variability were observed for the five species of Cola. Deductions from this study, showed that these quantitative descriptors are good determinants for characterizing Cola species.

The performance of each species showed that the different Cola species are similar for one or more characters and are related to each other and could therefore be grouped together. This confirms the work of Whittal [6] who suggested that some species of the same genus can be morphologically very similar and may be grouped into the same species despite the fact that they represent separate taxonomic entities.

Deductions from the results showed that each location contributed to variations in the vegetative morphological characters [7]. This was attributed to the environmental factors that influenced the nature of the leaf vegetative characters. On the other hand, the species also revealed high significance for the quantitative descriptors chosen. This species effect indicates the inherent hereditary contributions to the phenotypic variations observed in the vegetative characters. It therefore appears that the uniqueness from individual Cola species is a function of the location and species effect [7]. This environmental factor could arise from the soil factors and climatic factors exerting strong effects on the phenotypic appearance of each OTUs used in this study. The environment is known to potentially influence the morphology and expression of compounds in plants [7 - 10].

Quantitative parameters from this study are in line with Pierre et al [11] who revealed a high coefficient of variation in Cola acuminata. Cronquist [12] also opined that there is significant morphological variation in the sterculiaceae family both within and across species. Again, the results from the quantitative analysis is in line with Oyefunke [13] on comparative phytochemical and organoleptic studies of five Cola species where it was indicated that similarities in chemical constituents is the reason for the five taxa being in the same genus Cola, while the differences is the reason for the five species exist as distinct species. Pierre et al. [11] evaluated seventeen accessions of Cameroun Cola acuminata germplasm in order to examine the variation based on 17 morphological traits and established a list of minimum descriptors observed in all morphological characters with high coefficient of variation of Cola acuminata and in every phase of growth indicating a large variation of accessions for these traits. Pierre et al. [11] also alleged that all morpho-quantitative descriptors studied are discriminant for the identification of Cola acuminata accessions. Importantly, some species of the same genus can be morphologically very similar and may be grouped into the same species despite the fact that they represent separate taxonomic entities [6]. In a related study, Chandran and Pandya [14] noticed a wide variation of morphological traits in the morphological characterization of 35 accessions belonging to 13 species of Arachis.

Qualitative analysis in this study, shows that there is Inter- and Intra- species similarities and variability. Each Cola OTUs is distinctively delimited from the rest. This phenotypic quality in the morphological traits makes each individual accession distinct from the others even though they might fall within the same species or within the genus. However, the proportion of similarity and dissimilarity for the qualitative traits becomes 
Wood and Ohimain; ARRB, 35(9): 1-13, 2020; Article no.ARRB.60214

Table 5. Twelve qualitative characters and their occurrence in 16 cola accessions

\begin{tabular}{|c|c|c|c|c|c|c|c|c|c|c|c|c|}
\hline OTUs & $\begin{array}{l}\text { Leaf } \\
\text { apex }\end{array}$ & $\begin{array}{l}\text { Leaf } \\
\text { margin }\end{array}$ & $\begin{array}{l}\text { Leaf } \\
\text { shape }\end{array}$ & $\begin{array}{l}\text { Leaf } \\
\text { base }\end{array}$ & $\begin{array}{l}\text { Leaf } \\
\text { surface }\end{array}$ & $\begin{array}{l}\text { Plant } \\
\text { height }\end{array}$ & $\begin{array}{l}\text { Flower } \\
\text { colour }\end{array}$ & $\begin{array}{l}\text { Fruit } \\
\text { surface }\end{array}$ & $\begin{array}{l}\text { Seed } \\
\text { colour }\end{array}$ & $\begin{array}{l}\text { Floral } \\
\text { size }\end{array}$ & $\begin{array}{l}\text { Fruit } \\
\text { width }\end{array}$ & $\begin{array}{l}\text { Fruit } \\
\text { length }\end{array}$ \\
\hline GCA & 0 & 0 & 0 & 0 & 0 & 1 & 0 & 0 & 0 & 0 & 0 & 3 \\
\hline $\mathrm{GCN}$ & 0 & 0 & 1 & 1 & 0 & 0 & 2 & 0 & 1 & 0 & 1 & 3 \\
\hline GCM & 0 & 1 & 2 & 2 & 0 & 2 & 1 & 1 & 0 & 2 & 1 & 0 \\
\hline GCG & 0 & 1 & 2 & 2 & 0 & 0 & 0 & 2 & 0 & 3 & 1 & 4 \\
\hline $\mathrm{NCN}$ & 0 & 0 & 1 & 1 & 0 & 0 & 2 & 0 & 0 & 0 & 0 & 1 \\
\hline NCA & 0 & 0 & 3 & 3 & 0 & 3 & 0 & 0 & 0 & 0 & 0 & 2 \\
\hline $\mathrm{NCL}$ & 1 & 0 & 4 & 1 & 0 & 0 & 3 & 3 & 1 & 4 & 0 & 2 \\
\hline $\mathrm{CCN}$ & 2 & 0 & 1 & 1 & 2 & 0 & 2 & 0 & 0 & 0 & 1 & 0 \\
\hline CCA & 3 & 0 & 5 & 4 & 0 & 0 & 1 & 0 & 0 & 0 & 2 & 0 \\
\hline$A C N$ & 2 & 0 & 5 & 1 & 2 & 0 & 2 & 0 & 1 & 0 & 0 & 2 \\
\hline $\mathrm{ACA}$ & 0 & 0 & 5 & 4 & 0 & 1 & 0 & 0 & 0 & 0 & 0 & 3 \\
\hline $\mathrm{ACM}$ & 2 & 1 & 0 & 1 & 0 & 2 & 1 & 1 & 2 & 2 & 1 & 4 \\
\hline$A C G$ & 4 & 1 & 7 & 3 & 0 & 4 & 0 & 2 & 0 & 3 & 3 & 3 \\
\hline NA CM & 2 & 1 & 0 & 1 & 0 & 2 & 1 & 1 & 2 & 2 & 2 & 2 \\
\hline NACA & 0 & 0 & 5 & 1 & 0 & 0 & 0 & 0 & 0 & 0 & 0 & 0 \\
\hline NACG & 4 & 1 & 6 & 2 & 1 & 5 & 0 & 2 & 3 & 3 & 0 & 2 \\
\hline
\end{tabular}

Where $0,1,2,3,4$ indicates the frequency of occurrence in the OTUs 
a determinant for delineating species. The leaf surface, seed colour, and plant height $(100 \%$, $75 \%$ and $66.7 \%$ respectively) show strong characters for delimiting species and accessions. This shows that the 5 out of the 12 qualitative descriptors are polymorphous. We can also deduce that the highest occurring traits are cuneate leaf base, acuminate leaf apex, entire leaf margin, and glabrous leaf surface. This result is in line with the findings of Manzano et al [15] who suggested that six leaf and petiole qualitative descriptors contributed in the variability of Colocasia esculenta (L) Scott germplasm. Pierre et al. [11] alleged that all morpho-qualitative characters are discriminant for the variability for the five Cola species. In the morphological characterization and agronomic evaluation of Arracacia xanthorrhiza collection, 26 out of 29 qualitative descriptors were polymorphous [16]. Pierre et al. [11] noted that clusters of Cola acuminata based on morpho-qualitative traits don't have the same structure.

The five Cola species shows strong inter species variability for the 16 OTUs used for the study. The high difference in gene diversity among 16 taxa reveals the presence of strong genetic structure between them and thus significant differences exist in the genotypic diversity among themselves. This finding is supported by results of Mohd et al. [17] using a RAPD marker, reported that genetic variation occurred among the three ginger cultivars from Malaysia. RAPD analysis has been found to be useful in differentiating closely related species [18]. The genetic relation through RAPD markers may provide reliable method for the identification of species than morphological characters [19]. There is a common trend of maintaining high genetic diversity within populations in tropical plants as reported by Hamrick and Loveless [20]. These results are also confirmatory with the finding of Huang et al. [21] who reported significant (high) genetic variations by RAPD markers in other species at cultivar level. This outcome is supported by Nayak et al. [22] who established that the main cause of polymorphism could be intra specific variation among different cultivars.

The results from the three-combine effect of the character sets (Quantitative, Qualitative and Molecular) used for this study shows that there is a consistent variability and similarities for the five Cola species. These variations are traceable to the environmental effects and inherent genetic effects. Despite the dendrogram for each character set reveal new clusters based on the data and analysis carried out the OTUs of the same species frequently align together to show intra- and inter- species relationship of different species of Cola. This consistency in their similarity is an indication that they are of the same ancestor (monophyletic) and the same genus. The vegetative characters have shown to be inconsistent both for the qualitative and quantitative traits. On the other hand, the reproductive characters like the seed colour, fruit length, seed shape were found to be relatively consistent. Cola acuminata, C. millenii and Cola nitida were found to be preferable for consistency of character across the five locations and is recommended for breeding purposes. Cola gigantea and Cola lepidota show highest variability.

\section{CONCLUSION}

It is important to note that each taxonomic entity used for this study is distinctively and phenotypically different from the other even though they are of the same species or the same genus. From this comparative analysis, it clear that the high polymorphic and variability effects noticed in both morphological and molecular analysis are traceable to the environmental effects and inherent genetic effects. This consistency in their similarity as observed with the cluster analysis and dendogram is an indication that they are of the same ancestor (monophyletic) and the same genus. Morphological and molecular dissimilarity is an indication of species uniqueness and habitat influence. The vegetative characters have shown to be inconsistent both for the qualitative and quantitative traits. On the other hand, the reproductive characters like the seed colour, fruit length, and seed shape were relatively consistent. The results showed that the OTUs whose cultivation regions are very close shows maximum similarity among them as compared to OTUs which are farther apart. These findings provide an important contribution in determining resourceful management strategies for breeders for Cola improvement program and it is recommended that further research on the variability of Cola species should continue.

\section{COMPETING INTERESTS}

Authors have declared that no competing interests exist. 


\section{REFERENCES}

1. Odebunmi E, Oluwaniyi O, Awolola G. Proximate and nutritional composition of kola nut (Cola ni-tida), bitter cola (Garcinia cola) and alligator pepper (Afromomum melegueta). Afri. J. Biotechnol. 2009;8(2):308-310.

2. Sonibare AM, Soladoye MO. Esan OO. Phytochemical and Antimicrobial studies of four species of Cola Schott \& Endl. (sterculiaceae). Afr. J. Tradit. Compl. Altern. Med. 2009;6(4):518522.

3. Kuome, C., Sacande, M. Cola nitida (Vent) Scholt and Endl., Seed Leaflet:111.

4. Zou Z, Zhang J. Morphological and molecular convergences in mammalian phylogenetics Nature Comm. 2006;7:12758.

5. Lawrence Al, Adesoye TR. Fasola. Genetic diversity in Cola acuminata and Cola nitida using RAPD primers. Genetika. 2019;51(1):227-23.

6. Whittall JB, Hellquist CB, Schneider EL, Hodges SA. Cryptic species in an endangered pondweed community (Potamogeton, Potamogetonaceae) Revealed by AFLP Markers. Am J Bot. 2004;91:2022-2029.

7. Folkers A, Hüve K, Ammann C, Dindorf T, Kesselmeier J, Kleist E, Kuhn U, Uerlings $\mathrm{R}$, Wildt J. Methanol emissions from deciduous tree species: Dependence on temperature and light intensity. Plant Biol. 2008;10(1):65-75.

8. Shen $\mathrm{H}$, Tang $\mathrm{Y}$, Muraoka H, Washitani I. Characteristics of leaf photosynthesis and simulated individual carbon budget in Primula mutans under contrasting light and temperature conditions. J Plant Res. 2008;121:191-200.

9. Braga MR, Adiar PM, Marabesi MA, deGodoy JRL. Effects of elevated $\mathrm{CO}_{2}$ on the phyto alexin production of two soybean cultivars differing in the resistance to stem canker disease. Environ Exp Bot. 2006;58(1-3):85-92.

10. Cybulskill WJ, Peterjohn WT, Sullivan JH. The influence of ultraviolet-B radiation on tissue quality and composition of loblolly pine (Pinus taeda L.) needles. Environ Exp Bot. 2000; 44(3): 231-241.
11. Pierre EO, Niemenak N, Ndoumou DO. Morphological variability of Cola acuminata ((Pal. De Beauv) Schott and Endl. Germplasm in Cameroon. Pakistan J. Biol. Sci. 2006;9:398-403.

12. Cronquist A. Chemical Plant Taxonomy. In: G. Bendz, and J. Santesson (Eds.), Chemistry. Botanical Classification. Proceedings of the $25^{\text {th }}$ Nobel Symposium, August 20-25. Academic Press, New York \& London; 1981.

13. Saliu JA, Olabiyi AA, Adefegha SA, Oyeleye S. Comparative evaluation of antioxidative properties and effects of aqueous extracts of Cola nitida and Vitex doniana on Fe2+-Generated oxidative stress in rat testes in vitro. Int. J. Biotechnol. 2016;5(2):15-25.

14. Chandran K, Pandya SM. Morphological characterization of Arachis species of section, Arachis. Plant Genet. Resourc. Newslett. 2000;121:38-41.

15. Manzano BA, Nodals AAR, Gutierrez FZ, Mayor and Alfonso CL. Morphological and isoenzyme variability of taro (Colocasia esculenta L. Schott) germplasm in Cuba. Plant Genetic Res. Newsletter. 2001;126:31-40.

16. Rosso CA, Medina $\mathrm{Cl}$, Lobo $\mathrm{M}$. Morphological characterization and agronomic evaluation of a Colombian collection of Arrachia (Arracacia xanthorrihiza Bancroft.) Plant Genetic Res. Newsletter. 2002;132: 22-29.

17. Mohd MA, Ibrahim $\mathrm{H}$, Khalid $\mathrm{N}$. Differentiation of three varieties of Zingiber officinale Rosc. by RAPD fingerprinting. Malaysian J. Sci. 2004;23:135-139.

18. Zhang HY, Li FS, He LL, Zhong HQ, Yang $\mathrm{QH}$, He SC. Identification of Sugarcane interspecies hybrids with RAPDs. Afr. J. Biotechnol. 2008;7(8):1072-1074.

19. Palai SK, Rout GR. Identification and genetic variation among eight varieties of ginger by using random amplified polymorphic DNA markers Plant Biotechnol. 2007;24:417-420.

20. Hamrick JL, Loveless MD. The genetic structure of tropical tree populations: associations with reproductive biology. In: Bock J.H., Linhart Y.B., editors. Plant Evolutionary Ecology. 1989;131-146.

21. Huang $H$, Layne DR, Kubisiak TL. Molecular characterization of cultivated pawpaw using RAPD markers. J. 
American Soc. Horticul Sci. 2003;128:8593.

22. Nayak S, Naik PK, Acharya LK, Pattnaik AK. Detection and evaluation of genetic variation in 17 promising cultivars of turmeric (Curcuma longa L.) using nuclear DNA content and RAPD markers Cytologia. 2006;71:49-75.

(c) 2020 Wood and Ohimain; This is an Open Access article distributed under the terms of the Creative Commons Attribution License (http://creativecommons.org/licenses/by/4.0), which permits unrestricted use, distribution, and reproduction in any medium, provided the original work is properly cited.

Peer-review history:

The peer review history for this paper can be accessed here:

http://www.sdiarticle4.com/review-history/60214 